\title{
Perception Regarding Ethical Rules Implemented in the Context of Corporate Governance: A Study in Banking Sector
}

\author{
Esin Benhur Aktürk ${ }^{1 *}$ \\ ${ }^{1}$ Istanbul Aydin University, Istanbul, Turkey, (ORCID: 0000-0001-5756-1042)
}

(First received 13 November 2019 and in final form 31 December 2019)

(DOI: 10.31590 /ejosat.643744)

\begin{abstract}
ATIF/REFERENCE: Aktürk, E. B. (2019). Perception Regarding Ethical Rules Implemented in the Context of Corporate Governance:
\end{abstract} A Study in Banking Sector. European Journal of Science and Technology, (17), 1347-1356.

\begin{abstract}
Purpose - Ethics, which constitute the behaviors that should be abided by or avoided by parties, are all material and non-material factors that include social, cultural, economic and scientific values that are the basis for inter-personal relationships, and are a discipline that deal with behavioral norms and rules such as correct or wrong, good or bad, which people have to abide by. In this regard, the purpose of this study is to demonstrate business ethics in corporate governance and assessment of the need for business ethics, ethical leader and ethical behaviors relationship in corporate governance, explanation of organizational ethical climate and its impacts on workers as well as perception of workers in banking sector regarding the ethical rules implemented in the context of corporate governance and the impacts of such rules.

Methodology- In this study, questionnaire method was used as data collection method and ten demographical questions as well as nine questions regarding ten ethical leadership scales, eleven ethical climate scales and five non-ethical behavior scales were asked in the questionnaire. This study is a relational screening model that reviews the relations among two different situations that can affect each other in terms of several variables. Findings- There were no statistically significant differences in terms of "ethical leadership" scale scores between males and females in this study and there was a significant difference in terms of "ethical leadership" and "ethical climate" between married and single individuals observed. The desire of married individuals to work in a more stable environment and tend to be less risky also lead to the valuing of ethical leadership and ethical climate. When we look at educational status and education areas, there was a statistically significant difference between "ethical leadership" and "ethical climate" scale scores.

Conclusion- This study is a guide and it will play a role and contribute to institutions in determining their own ethics and spreading this ethics to the personnel working at bank through training to be given to employees of the institution. It is foreseen that the banking structure, which is a growing and spreading system, can develop even more with the ethical rules internalized by the employees in addition to the the written ethical rules, which can affect the business loyalty and motivation of the employees in the bank.
\end{abstract}

Keywords: Ethical, Ethical Leadership, Ethical Climate,Corporate Governance,Ethical Rules.

\section{Introduction}

Ethics, which constitute the behaviors that should be abided by or avoided by parties, are all material and non-material factors that include social, cultural, economic and scientific values that are the basis for inter-personal relationships, and are a discipline that deal with behavioral norms and rules such as correct or wrong, good or bad, which people have to abide by. In organizations, the legislations, regulations and other administrative elements that are already in effect sometimes may be inadequate for defining the administrative operation of the organizations. Ethical codes are used for resolving problems that could be encountered in such cases, and they also carry great importance for establishing the cultural structure. An ethical leader, who embodies the ethical qualities and who could ensure that the people around him behave in accordance with such ethical values, is needed to establish the cultural structure and great responsibility is conferred on ethical leaders with regards to ensuring order. The elements that reveal a leader explain why that leader

* Corresponding Author: Istanbul Aydin University, Istanbul, Turkey, (ORCID: 0000-0001-5756-1042), esinakturk@aydin.edu.tr 


\section{European Journal of Science and Technology}

is essentially there. When leadership is discussed, primarily administratorship is addressed and whether the individuals at administrative positions possess leadership qualities is discussed. With regards to this, it cannot be expected from every administrator to carry leader qualities, however one should possess leader qualities if one is to become a good administrator. Any statement that could be made related with necessity towards ethical values in the social life similarly applies for work life. The reason for this is that in the absence of ethical values, one would be faced with certain risks with regards to both business processes and business continuity. The purpose of the study is to evaluate business ethics in corporate governance and the requirement for business ethics, to explain the relationship between ethical leader and ethical conduct in corporate governance, organizational ethics climate and its influence on the employees, as well as to reveal the banking sector employees' perception of ethical rules implemented within the frame of organizational management and the effects of such perception. The study covers banking institutions operating in İstanbul Province Sişli district. The permits required for the study were obtained from the firm operating in the Şişli region and the survey study was carried out. Many of the employees rejected participating in the study with the excuse that they were too busy. No information that would reflect the participants' personal characteristics or the firm identity was present on the survey form prepared for the study. It cannot be said that the results obtained from the study concern the entirety of service businesses. The study's participants rejecting to fill survey forms because they were too busy constituted a restriction for the study.

\section{Business Ethics, Ethical Leadership and Organizational Ethics Climate in Corporate Governance}

\subsection{The Ethics}

Ethics fundamentally and principally conceptualizes the problems regarding behaviour types and rules that people are obliged to comply with. Accordingly it goes beyond which of the tangible elements are correct and which are required and then illustrates the universally consented rules and based on these rules provides guidance regarding which have priority. Any decision on the correctness of an issue is made within the frame of ethical values(Acar,A.,2013:5-31). Ateş and Oral (2003), state that historically the notion of ethics was mostly associated with politics and the focus was on the morals of the leader (Akdoğan ve Demirtaş,2014:107-123). Ethics are the moral principles that defined new rules in order to create a life style which embodies all outstanding attributes that could be designed by thought providing alternatives to the entirety of material and moral elements that encompass the exiting social, cultural, economic and scientific values and examines the lifestyles of people which was accepted as the requirement of a the period they were in, in order to find and show the right and wrong aspects (Ateş ve Oral,2003:55-71). Ethics, which constitute the behaviors that should be abided by or avoided by parties, are all material and non-material factors that include social, cultural, economic and scientific values that are the basis for inter-personal relationships, and are a discipline that deal with behavioral norms and rules such as correct or wrong, good or bad, which people have to abide by. Ethics is a field that investigates the whole of material and moral elements which include the social, cultural, economic and scientific values by getting to the core and handles the problems associated with the value judgments of people in the social life (Aydın,2016:300). Accordingly, the ethics phenomenon is firstly established by studying the expected and aimed lifestyle and on how to behave in a macro scale, what should happen and the what material and moral elements which include the social, cultural, economic and scientific values which should be observed should be. The importance of ethics in man's social life with respect to social status is undeniable. Wherever the society has placed ethics, its reflection on individuals will be in that way, too (Aykanat,2010:100).

\subsection{Business Ethics in Corporate Governance}

Eren (2012) emphasizes the applicability of the entire range of behaviors to be avoided or avoided in the framework of corporate governance, personal moral values, the applicability of activities to the activities and objectives of commercial organizations and emphasizes that their values in relation to each other in the organization express their moral (Barnett ve Schubert,2002:279-290). Leaning towards business ethics is an opportunity both for the wage earners and as well as the organizations. Wage earners and organizations must strive to implement the values accepted as humanitarian values in their business lives. This is the only way through which knowledge can be gained regarding the whole of behaviors which the professions must abide by or avoid within the frame of corporate governance (Brown,Trevino and Harrison,2005:117-134). Universal values related with business life are needed due to the business life growing volume-wise like never seen before, the wage earners' demographic structure exceeding the controllable diversity levels, international organizations' rapidly multiplying and similar reasons. The factors that supported the coming into prominence of the topic of the whole of behaviors that professions require to abide by or avoid within the frame of corporate governance which gained importance particularly after 1990's are; The social responsibility approach that developed with public pressure, correct business can be done only by taking ethical values into account, ethical knowledge is needed to solve problems, the requirement for loyalty towards the whole of behaviors that professions require to abide by or avoid within the frame of corporate governance for successful administrative processes and the requirement to balance various beneficiary circles in business life and other similar factors. Individuals not being able to find a place to work in the fields they are talented in; the capitalist system's primary disposition of doing more work with less personnel and the existence of a populace that cannot find a place to work due to rapidly increasing world population and for which no new work fields are created, are important factors for the necessity of corporate business ethics. If working areas are not created for people to allow them to meet both their personal and their family's needs, they are sure to divert to illegal means in order to meet their requirements. This will pose a serious problem both to the business world as well as for the society (Byrne,1989:200).

\subsection{Ethical Leadership in Corporate Governance}

The process of an individual influencing another individual's behavior and directing another individual's behavior, within certain conditions in order to achieve individual or corporate targets is called leadership. The leader is able to internalize different styles while fulfilling responsibilities. Leadership, considering its meaning, essentially expresses the position an individual takes. Leadership can be accepted as a function with respect to meeting individual and social requirements (Demirdağ ve Ekmekçioğlu, 2015:197-216). An e-ISSN: $2148-2683$ 


\section{Avrupa Bilim ve Teknoloji Dergisi}

ethical leader is an individual who is fair, values individuals and social circles behaves according to principles and both in private life and in business life behaves according to the whole of behaviors which the professions must abide by or avoid within the frame of corporate governance, and ensures that the wage earners he leads behave ethically (Doğan ve Kılıç,2014:103-132). Brown, Trevino and Harrison (2005) have indicated that ethical leadership have appropriate rules for personal actions and inter-personal relationships and emphasized that it is about shedding light on human resources through communication, encouragement and decision making (Eren,2012:100). Brown et al. (2005) have emphasized one of the characteristic qualities of ethical leadership and asserted that the personal behavior and human relationships of the ethical leader are congruent. Brown et al. propounded that leaders complying with the whole of behaviors which the professions must abide by or avoid within the frame of corporate governance had four fundamental qualities and emphasized these qualities as; honesty, trustworthiness, fairness and compassion. Accordingly, it becomes evident that the two fundamental virtues that form the basis of a leadership that is compatible with the whole of behaviors which the professions must abide by or avoid within the frame of corporate governance, are justice and morality. The most important responsibility of the ethical leaders in Corporate Governance is to give the ethical messages at the work place in a clear and comprehensible manner. The more transparent and fair a leader is, the more the ethics perception in corporate governance develops(Eren,2012:100). Murphy and Enderle (1995) have conducted a comprehensive study aimed at determining the characteristics of the leader, taking into consideration the leadership characteristics of 4 well-known top managers and have presented the characteristics of ethical leadership. They emphasized that first of all the ethical leader acted as a lens and exactly reflected whatever was the case and secondly the ethical leader allowed for intelligent awareness through his behavior and also took his influence on other people into consideration. Thirdly they emphasize that the ethic leader exhibits top level virtue ethics and behaves fairly and artlessly both in professional and personal life. Finally, they express that the Ethical Leader directs others with value and justice since he believes it is the right thing to do (Kline,2011:120)

\subsection{Organizational Ethics Climate in Corporate Governance}

Facing global expansion and growth over what is expected, caused by the change in the economic world, renders business ethics more important. The ethical perception within the organization determines the climate structure which conforms to the whole behaviors that should be obeyed or avoided by the profession branches in the framework of corporate governance that composed of the institutionalized guiding principles and norms of the institution. This situation, which has a significant effect on decision-making processes, also contributes to the development of ethical considerations of the staff (Murphy and Enderle,1995:117-128)

The support of ethical practices in provision of the confidence atmosphere is returning to the institutions as an advantage. Within the frame of corporate governance, they have a network of trust consisting of staff, managers, stakeholders and target groups who have values that are consistent with the behaviors that must be obeyed or avoided by the profession. Within the frame of corporate governance, they have a network of trust consisting of staff, managers, stakeholders and target groups who have values that are consistent with the whole behaviors that must be obeyed or avoided by the profession branches. Institutional climate is the behaviors expected from the staff, supported and rewarded as a result of success in parallel with the ethical and moral values. In organizations, different understandings such as democratic, authoritarian, reliable or unreliable, preventive or supportive, work- or personnel-oriented and so on can be evaluated differently by every employee within the functioning of the institution and reflect a fairly natural process While the institution develops its own climate, it takes into consideration the ethical elements and indicates the attitudes expected by it from each institution member in terms of it feasibility. In this context, the climate consistent with the whole behaviors that must be respected or avoided by the professional branches in the framework of effective corporate governance established by senior executives within the organization and perceived positively by the staff, affects the performance positively by promoting the emotional tendency towards the role of the personnel in their job(Özgener,2002:175-199) Minimizing the stress levels of employees and performance increase in work satisfaction through morale and motivation also reflect positively to efficiencies of the working groups they are involved in. While this situation directly affects performance of the institution, efficiency increases on a direct proportional basis. Modern organizations adopt management understandings to combine their ethical understanding with corporate practices. In corporate governance, especially in the recent period, the tendency in creating an ethical also caused increase in factors such as motivation of staff, job satisfaction etc. and aids of the ethical environment for discipline of employees and creation of a fair environment reached a level that cannot be denied.

\section{Methodology}

Since we can not reach the net number of people working in the banking sector in Turkey, we have chosen a sampling calculation with unknown universe when calculating the sample size. Accordingly, in order to work with a 5\% error margin with the unknown universe, 302 subjects have to be interviewed. However, considering that some subjects would be discaded due to some of the questionnaires not being of the quality desired, a sample consisting of 310 subjects was used. As a result of a final sorting and discarding of incorrect questionnaires, the analysis was carried out on 300 questionnaires. Therefore, the sample of our study consisting of 300 subjects includes a $\pm \% 5$ error margin in the $90 \%$ confidence interval, and is of a level which can represent the total population of workers in the banking industry in Turkey. In the survey, bank employees were selected by simple random sampling method.

\subsection{Ethical Leadership Scale , Business Ethical Climate Scale and Non-Ethical Behavior Scale}

10-item scale developed by Brown et al. in 2005 was used to measure ethical leadership. The appropriateness, validity and reliability in Turkish language and removing the misunderstandings arising from the cultural differences of the scale was carried out in 2012 by Tuna, Bircan and Yeşiltaş. As a result of the validity study, a one-factor structure in accordance with the original form of the scale was created(Pettijohn,2008:547-557).

The ethical climate was assessed by a 7-point scale developed by Schwepker et al. (1997) [16] based on the scale developed by Qualls and Puto in 1989. There is no reverse entry on the one dimensional scale. The scale is of 5 Likert type. The scale adapted to Turkish was used (Murphy and Enderle,1995:117-128). The anti-social behavior measurement questionnaire by Robinson and O'Leary in 1998 was used to measure unethical behaviors. Robinson and O'Leary-Kelly (1998) use the commonly used concept of antisocial e-ISSN: 2148-2683 
behavior to describe negative behaviors in organizations. Antisocial behavior is known as the opposite of prosocial behavior. The questionnaire consists of 9 questions(Sayğan,2013:1-23).

\subsection{Study Design and Model and Analysis of Study Data}

The study was created based on the relational screening model. The relational screening model is a research model that aims to determine the degree or presence of change between two or more variables.

Survey form data was transferred to SPSS 21.0 data analysis program and necessary analysis carried out. The descriptive statistics of the continuous variables included in the study are shown as mean, standard deviation, median, minimum and maximum values, and categorical variables as frequency and percentage. Normal distribution of continuous variables was investigated by Shapiro Wilk test. Mann Whitney U test was used for 2 group comparisons and Kruskal Wallis test was used for 3 and more group comparisons; while Mann Whitney U test with Bonferroni correction was used for 2 subgroup comparisons for meaningful variables. Comparisons with a $\mathrm{p}$ value below 0.05 were considered statistically significant in all statistical analysis in the study.

\subsection{Reliability Analysis of Scales}

As seen in the table below, the reliability level of the Ethical Leadership Scale $($ Cronbach's alpha $=.901)$ is seen to be quite high. The Ethical Climate Questionnaire (Cronbach's alpha $=.951)$ and the Ethical Behavior Questionnaire (Cronbach's alpha $=.832)$ were found to have significantly higher "reliability" scores.

Table 1: Reliability Analysis of Scales

\begin{tabular}{|l|c|c|}
\hline & Cronbach's Alpha & N of Items \\
\hline Ethical Leadership Scale &, 901 & 10 \\
\hline Ethical Climate Scale &, 951 & 11 \\
\hline Unethical Behavior Scale &, 832 & 9 \\
\hline
\end{tabular}

\subsection{Structural Equation Model of the Study}

As a result of the analysis made, $\chi^{2}=1197,114(\mathrm{df}=402, \mathrm{p}<.001)$ value was obtained regarding the structure of 3 factorial scale consisting of 30 items. According to the results obtained, Chi square value is expected to be meaningless, but this value is very sensitive to the sample size and can often be found at significant levels in large sample groups. From this point of view, a calculation which is obtained from the fraction of the freedom degree of the Chi square ratio obtained as an alternative is suggested [18]. This ratio was found to be $\left(\chi^{2} / \mathrm{df}=2.98\right)$ in the study. If this ratio is three or less, the model is a good model, and if it is five or less, it shows that the model has an acceptable adaptability [19]. The value obtained from this is an important proof that the model is an acceptable model. In addition, Goodness of Fit Index (GFI), Adjusted Goodness of Fit Index (CFI), Comperative Fit Index (CFI), Root Mean Square Error of Approximation (RMSEA) and Standardized Root Mean Square Residual (SRMR) compliance indices were also calculated. Although the acceptability levels of the indicated compliance indices vary according to different authors, it is generally acceptable to have a GFI, AGFI and CFI of .90 and above, with RMSEA under .08 and SRMR under .10 [20]. The values obtained for the adjusted compliance indices in the study were calculated as $\mathrm{GFI}=.91, \mathrm{AGFI}=.90, \mathrm{CFI}=.92$ and $\mathrm{RMSEA}=.056$. These compliance index values show that the model is a good fit.

\section{Figure 1: Structural Equation Model}

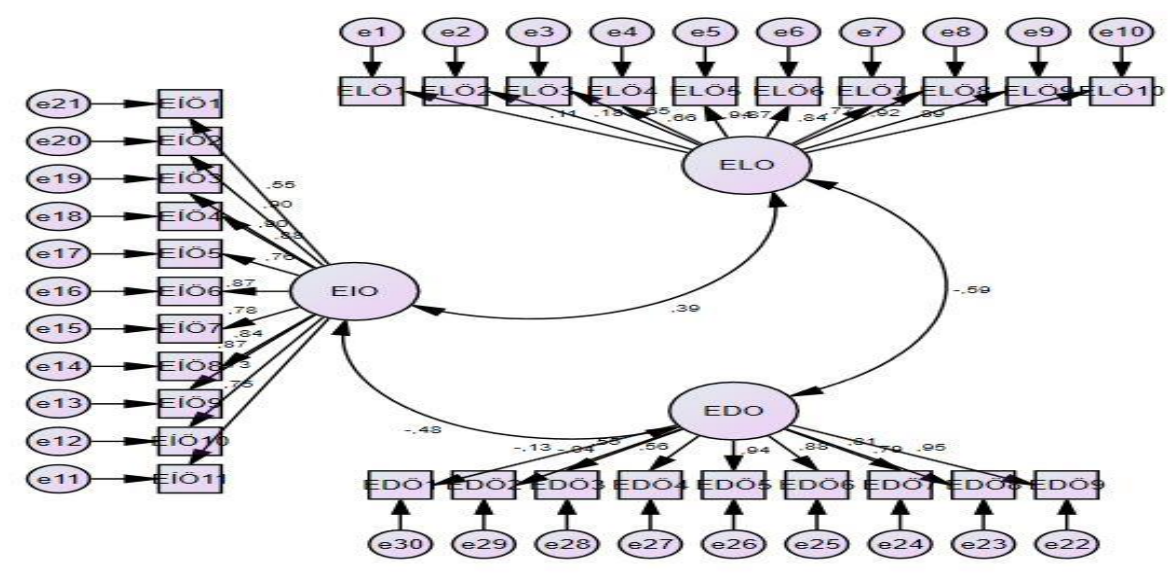




\section{Findings}

\subsection{Findings Related To Frequency Analysis}

Survey form data to SPSS 21.0 data analysis program the necessary analyzes were made. Study included descriptive statistics on continuous variables,Standard deviation, median, minimum and maximum values, categorical variables with frequency and percentage It is shown. Normal distribution of continuous variables The suitability was examined by Shapiro Wilk test. Normal 2 groups of nondistributed variables Mann Whitney U test in comparison, 3 and more Kruskal Wallis test was used for group comparisons; subgroup comparisons for significant variables Mann Whitney U test with Bonferonni correction for used. In all statistical analyzes in the study Comparisons under 0.05 were statistically statistically considered significant.

Table 2: Participants' Demographic Characteristics

\begin{tabular}{|c|c|c|c|c|c|}
\hline Gender & f & $\%$ & Marital Status & f & $\%$ \\
\hline Female & 158 & 52,7 & Single & 77 & 25,7 \\
\hline Male & 142 & 47,3 & Married & 223 & 74,3 \\
\hline Age & $f$ & $\%$ & Education Status & $f$ & $\%$ \\
\hline Under 30 Years & 70 & 23,3 & Degree & 42 & 14,0 \\
\hline 30- Between 40 Years & 153 & 51,0 & Degree & 182 & 60,7 \\
\hline 41- Between 50 Years & 55 & 18,3 & Post Graduate & 65 & 21,7 \\
\hline 51- Between 60 Years & 22 & 7,3 & Doctorate & 11 & 3,7 \\
\hline Position & $f$ & $\%$ & \multirow{2}{*}{\multicolumn{3}{|c|}{ Risk Management Assurance Certificate }} \\
\hline Personnel & 170 & 56,7 & & & \\
\hline Sub- Level Manager & 78 & 26,0 & Yes & 89 & 29,7 \\
\hline Manager & 52 & 17,3 & No & 211 & 70,3 \\
\hline Graduated Faculty & f & $\%$ & Derivative Instruments & f & $\%$ \\
\hline $\begin{array}{l}\text { Economics and } \\
\text { Administrative Science }\end{array}$ & 214 & 71,3 & Yes & 154 & 51,3 \\
\hline Engineering Architecture & 22 & 7,3 & No & 146 & 48,7 \\
\hline Distance Education & 48 & 16,0 & \multicolumn{3}{|l|}{ Credit Rating License } \\
\hline Communication Faculty & 16 & 5,3 & Yes & 134 & 44,7 \\
\hline Has Children & $f$ & $\%$ & No & 166 & 55,3 \\
\hline Yes I have Children & 170 & 56,7 & Housing Val. License & f & $\%$ \\
\hline I Have No Children & 130 & 43,3 & Yes & 135 & 45,0 \\
\hline SPK 1 & f & $\%$ & No & 165 & 55,0 \\
\hline Yes & 147 & 49,0 & & & \\
\hline No & 153 & 51,0 & & & \\
\hline \multicolumn{6}{|c|}{ Grand Total=300 } \\
\hline
\end{tabular}

\subsection{Comparisons Based on Socio-Demographic Characteristics}

Of the 300 people included in the study, $70(23.3 \%)$ were under the age of 30,153 (51\%) aged between 30-40 years, $55(18.3 \%)$ 41-50 years old and $22(7.3 \%)$ were between 51-60 years of age. Of the 300 people included in the study, 158 (52.7\%) were female, 142 $(47.3 \%)$ were male. Of the 300 people included in the study, 77 (25.7\%) were single, 223

(74.3\%) are married. Of the 300 people included in the study, 170 (56.7) children while there were $130(43.3 \%)$ children. 42 of the 300 participants (14\%) are associate's while $182(60.7 \%)$ bachelors, $65(21.7 \%)$ graduate (11.7\%) and Ph.D. 
European Journal of Science and Technology

Table 3: Gender Comparisons

\begin{tabular}{|c|c|c|c|c|}
\hline & Female & Male & \multirow{2}{*}{$\mathbf{z}$} & \multirow{2}{*}{$\mathbf{p}$} \\
\hline & $(n=158)$ & $(n=142)$ & & \\
\hline \multirow{2}{*}{ Ethical Leadership } & $3.70 \pm 0.84$ & $3.77 \pm 0.81$ & \multirow{2}{*}{-0.658} & \multirow{2}{*}{0.511} \\
\hline & $3,65(1,70-5,00)$ & $3,95(1,70-5,00)$ & & \\
\hline \multirow{2}{*}{ Ethical Climate } & $4.10 \pm 0.82$ & $3.92 \pm 1.05$ & \multirow{2}{*}{-1.077} & \multirow{2}{*}{0.281} \\
\hline & $4.36(1.82-5.00)$ & $4.27(1.00-5.00)$ & & \\
\hline \multirow{2}{*}{ Unethical Behavior } & $2.63 \pm 0.75$ & $2.65 \pm 0.80$ & \multirow{2}{*}{-0.097} & \multirow{2}{*}{0.923} \\
\hline & $2.56(1,11-4,89)$ & $2.56(1,11-4,44)$ & & \\
\hline
\end{tabular}

There is no statistically significant difference in terms of "ethical leadership" scale score between males and females ( $p=0,511)$. There is no statistically significant difference in terms of "ethical climate" scale score between males and females ( $p=0,281$ ). So H02 hypothesis is accepted. There is no statistically significant difference in terms of "unethical behaviour" scale score between males and females $(\mathrm{p}=0,923)$. So H03 hypothesis is accepted.

Table 4: Comparisons According to Marital Status

\begin{tabular}{|c|c|c|c|c|}
\hline \multirow{2}{*}{ Ethical Leadership } & Single & Married & \multirow{2}{*}{ z } & p \\
\cline { 2 - 3 } & $\mathbf{( n = 7 7 )}$ & $\mathbf{( n = 2 2 3 )}$ & & \\
\cline { 2 - 4 } & $3.57 \pm 0.77$ & $3.79 \pm 0.84$ & \multirow{2}{*}{-1.981} & \multirow{2}{*}{$\mathbf{0 . 0 4 8}$} \\
\cline { 2 - 4 } Ethical Climate & $3.90 \pm 0.86$ & $4.05 \pm 0.96$ & \multirow{2}{*}{-2.175} & \multirow{2}{*}{$\mathbf{0 . 0 3}$} \\
\cline { 2 - 4 } & $4,18(1,64-5,00)$ & $4.36(1.00-5.00)$ & & \\
\hline \multirow{2}{*}{ Unethical Behavior } & $2.61 \pm 0.72$ & $2.65 \pm 0.79$ & \multirow{2}{*}{-0.562} & \multirow{2}{*}{0.574} \\
\cline { 2 - 4 } & $2.56(1,11-4,33)$ & $2,67(1,11-4,89)$ & & \\
\hline
\end{tabular}

There is a statistically significant difference in terms of "ethical leadership" scale score between married and single individuals $(\mathrm{p}<0,048)$. There is a statistically significant difference in terms of "ethical climate" scale score between married and single individuals $(\mathrm{p}<0,030)$. There is no statistically significant difference in terms of "unethical behaviour" scale score between maried and single individuals $(\mathrm{p}=0,574)$.

Table 5: Comparisons by Age

\begin{tabular}{|c|c|c|c|c|c|c|}
\hline & Under $\mathbf{3 0}$ years & $30-40$ years & $41-50$ years & $51-60$ years & \multirow{2}{*}{$\begin{array}{c}\text { Chi- } \\
\text { square }\end{array}$} & \multirow{2}{*}{$\mathbf{p}$} \\
\hline & $(n=70)$ & $(n=153)$ & $(n=55)$ & $(n=22)$ & & \\
\hline \multirow{2}{*}{$\begin{array}{c}\text { Ethical } \\
\text { Leadership }\end{array}$} & $3.60 \pm 0.75$ & $3.59 \pm 0.76$ & $3.86 \pm 0.90$ & $4.84 \pm 0.27$ & \multirow{2}{*}{52.05} & \multirow{2}{*}{$<0.001$} \\
\hline & $3.60(2.0-4.90)$ & $3.60(1.70-4.9)$ & $4.00(2.0-5.0)$ & $5.00(4.4-5.0)$ & & \\
\hline \multirow{2}{*}{$\begin{array}{l}\text { Ethical } \\
\text { Climate }\end{array}$} & $3.90 \pm 0.94$ & $3.97 \pm 0.88$ & $3.91 \pm 1.07$ & $4.95 \pm 0.05$ & \multirow{2}{*}{51.246} & \multirow{2}{*}{$<0.001$} \\
\hline & $4.18(1.64-5.0)$ & $4.18(1.0-5.0)$ & $4.27(1.27-5.0)$ & $5.00(4.82-5.0)$ & & \\
\hline \multirow{2}{*}{$\begin{array}{l}\text { Unethical } \\
\text { Behavior }\end{array}$} & $2.59 \pm 0.74$ & $2,62 \pm 0,75$ & $2.83 \pm 0.89$ & $2.44 \pm 0.67$ & \multirow{2}{*}{4.35} & \multirow{2}{*}{0.226} \\
\hline & $2.56(1.11-4.0)$ & $2.56(1,11-4,44)$ & $2.68(1.22-4.89)$ & $2.39(1.44-3.78)$ & & \\
\hline
\end{tabular}

There is a statistically significant difference in terms of "ethical leadership" scale score among age groups ( $<<0,001)$. There is a statistically significant difference in terms of "ethical climate" scale score among age groups $(\mathrm{p}<0,001)$. There is no statistically significant difference in terms of "unethical behaviour" scale score among age groups $(\mathrm{p}=0,226)$.

Table 6: Comparisons According to Being Parents

\begin{tabular}{|c|c|c|c|c|}
\hline & Has Children & No children & \multirow{2}{*}{$\mathbf{z}$} & \multirow{2}{*}{ p } \\
\hline & $(n=170)$ & $(n=130)$ & & \\
\hline \multirow{2}{*}{ Ethical Leadership } & $3.80 \pm 0.86$ & $3.65 \pm 0.76$ & \multirow{2}{*}{-1.852} & \multirow{2}{*}{0.064} \\
\hline & $3,95(1,70-5,00)$ & $3.80(1.70-5.00)$ & & \\
\hline \multirow{2}{*}{ Ethical Climate } & $4.04 \pm 0.99$ & $3.98 \pm 0.87$ & \multirow{2}{*}{-1.472} & \multirow{2}{*}{0.141} \\
\hline & $4.36(1.00-5.00)$ & $4,18(1,64-5,00)$ & & \\
\hline \multirow{2}{*}{ Unethical Behavior } & $2.69 \pm 0.81$ & $2.57 \pm 0.71$ & \multirow{2}{*}{-1.259} & \multirow{2}{*}{0.208} \\
\hline & $2,67(1,22-4,89)$ & $2.56(1,11-4,33)$ & & \\
\hline
\end{tabular}




\section{Avrupa Bilim ve Teknoloji Dergisi}

There is a statistically significant difference in terms of "ethical leadership" scale score among those with children and without $(p=0,064)$. There is no statistically significant difference in terms of "ethical climate" scale score among those with children and without $(\mathrm{p}=0,141)$. There is no statistically significant difference in terms of "unethical behaviour" scale score among those with children and without $(\mathrm{p}=0,208)$.

Table 7: Comparisons by Education Level

\begin{tabular}{|c|c|c|c|c|c|}
\hline & Associate Degree & Degree & Graduate / Doctorate & \multirow{2}{*}{$\begin{array}{c}\text { Chi- } \\
\text { square }\end{array}$} & \multirow{2}{*}{$\mathbf{p}$} \\
\hline & $(n=42)$ & $(n=182)$ & $(n=76)$ & & \\
\hline \multirow{2}{*}{$\begin{array}{c}\text { Ethical } \\
\text { Leadership }\end{array}$} & $3.58 \pm 0.83$ & $3.62 \pm 0.81$ & $4.09 \pm 0.76$ & \multirow{2}{*}{19.817} & \multirow{2}{*}{$<0.001$} \\
\hline & $3.70(2.00-4.90)$ & $3,65(1,70-5,00)$ & $4.40(2.20-5.00)$ & & \\
\hline \multirow{2}{*}{$\begin{array}{l}\text { Ethical } \\
\text { Climate }\end{array}$} & $3.66 \pm 1.10$ & $3.98 \pm 0.90$ & $4.29 \pm 0.85$ & \multirow{2}{*}{17.268} & \multirow{2}{*}{$<0.001$} \\
\hline & $4,00(1,00-5,00)$ & $4.27(1.09-5.00)$ & $4.64(1.91-5.00)$ & & \\
\hline \multirow{2}{*}{$\begin{array}{l}\text { Unethical } \\
\text { Behavior }\end{array}$} & $2.73 \pm 0.85$ & $2.65 \pm 0.76$ & $2.57 \pm 0.76$ & \multirow{2}{*}{0.734} & \multirow{2}{*}{0.693} \\
\hline & $2,67(1,11-4,44)$ & $2.56(1,11-4,89)$ & $2.61(1.22-4.22)$ & & \\
\hline
\end{tabular}

There is a statistically significant difference in terms of "ethical leadership" scale score among education groups ( $p<0,001)$. There is a statistically significant difference in terms of "ethical climate" scale score among education groups ( $p<0,001)$. There is no statistically significant difference in terms of "unethical behaviour" scale score among education groups ( $p=0,693)$.

Table 8: Comparisons by Area of Education

\begin{tabular}{|c|c|c|c|c|c|c|}
\hline & $\begin{array}{c}\text { Economic } \\
\text { Administration }\end{array}$ & Engineering & $\begin{array}{l}\text { Distance } \\
\text { Education }\end{array}$ & Communication & \multirow{2}{*}{$\begin{array}{l}\text { Chi- } \\
\text { square }\end{array}$} & \multirow[t]{2}{*}{ p } \\
\hline & $(n=214)$ & $(n=22)$ & $(n=48)$ & $(n=16)$ & & \\
\hline \multirow{2}{*}{$\begin{array}{c}\text { Ethical } \\
\text { Leadership }\end{array}$} & $3.76 \pm 0.81$ & $3.77 \pm 0.88$ & $3.59 \pm 0.87$ & $3.75 \pm 0.81$ & \multirow{2}{*}{1.291} & \multirow{2}{*}{0.731} \\
\hline & $3.90(1.70-5.00)$ & $3.80(1.90-5.00)$ & $3.60(2.00-5.00)$ & $4.10(2.20-4.80)$ & & \\
\hline \multirow{2}{*}{$\begin{array}{l}\text { Ethical } \\
\text { Climate }\end{array}$} & $4.08 \pm 0.89$ & $4.37 \pm 0.70$ & $3.69 \pm 1.06$ & $3.59 \pm 1.15$ & \multirow{2}{*}{10.28} & \multirow{2}{*}{0.016} \\
\hline & $4.36(1.09-5.00)$ & $4.55(2.27-5.00)$ & $4,00(1,00-5,00)$ & $3.95(1.91-4.82)$ & & \\
\hline \multirow{2}{*}{$\begin{array}{l}\text { Unethical } \\
\text { Behavior }\end{array}$} & $2,62 \pm 0,75$ & $2.51 \pm 0.76$ & $2.75 \pm 0.87$ & $2.78 \pm 0.84$ & \multirow{2}{*}{2.031} & \multirow{2}{*}{0.566} \\
\hline & $2.56(1,11-4,89)$ & $2.50(1.11-4.00)$ & $2,67(1,11-4,44)$ & $2.72(1.22-4.00)$ & & \\
\hline
\end{tabular}

There is no statistically significant difference in terms of "ethical leadership" scale score between faculty groups ( $p=0,731$ ). There is a statistically significant difference in terms of "ethical climate" scale score between faculty groups ( $\mathrm{p}=0,016)$. There is no statistically significant difference in terms of "unethical behaviour" scale score between faculty groups $(\mathrm{p}=0,566)$.

Table 9: Comparisons According to Holding Capital Markets Activities Level-1 License

\begin{tabular}{|c|c|c|c|c|}
\hline & \multicolumn{2}{|c|}{ Holding Capital Markets Activities Level-1 License } & \multirow{3}{*}{$\mathbf{z}$} & \multirow{3}{*}{ p } \\
\hline & Yes & No & & \\
\hline & $(n=147)$ & $(n=153)$ & & \\
\hline \multirow{2}{*}{ Ethical Leadership } & $3.81 \pm 0.85$ & $3.66 \pm 0.79$ & \multirow{2}{*}{-1.535} & \multirow{2}{*}{0.125} \\
\hline & $4,00(1,70-5,00)$ & $3.80(1.70-5.00)$ & & \\
\hline \multirow{2}{*}{ Ethical Climate } & $4.16 \pm 0.90$ & $3.87 \pm 0.95$ & \multirow{2}{*}{-3.339} & \multirow{2}{*}{0.001} \\
\hline & $4.45(1.09-5.00)$ & $4,18(1,00-5,00)$ & & \\
\hline \multirow{2}{*}{ Unethical Behavior } & $2.59 \pm 0.75$ & $2.69 \pm 0.79$ & \multirow{2}{*}{-1.072} & \multirow{2}{*}{0.284} \\
\hline & $2.56(1,11-4,33)$ & $2,67(1,11-4,89)$ & & \\
\hline
\end{tabular}

There is a statistically significant difference in terms of "ethical leadership" scale score among those with the license in question and without $(\mathrm{p}=0,125)$. There is a statistically significant difference in terms of "ethical climate" scale score among those with the license in question and without $(\mathrm{p}<0,001)$. There is a statistically significant difference in terms of "unethical behaviour" scale score among those with the license in question and without $(\mathrm{p}=0,284)$. 
Table 10. Comparisons According to Holding Derivative Instruments License

\begin{tabular}{|c|c|c|c|c|}
\hline & \multicolumn{2}{|c|}{ Holding Derivative Instruments License } & \multirow{3}{*}{$\mathbf{z}$} & \multirow{3}{*}{ p } \\
\hline & Yes & No & & \\
\hline & $(n=154)$ & $(n=146)$ & & \\
\hline \multirow{2}{*}{ Ethical Leadership } & $3.79 \pm 0.82$ & $3.67 \pm 0.82$ & \multirow{2}{*}{-1.034} & \multirow{2}{*}{0.301} \\
\hline & $3.80(1.70-5.00)$ & $3.90(1.70-5.00)$ & & \\
\hline \multirow{2}{*}{ Ethical Climate } & $4.07 \pm 0.96$ & $3.95 \pm 0.92$ & \multirow{2}{*}{-1.988} & \multirow{2}{*}{0.047} \\
\hline & $4.36(1.64-5.00)$ & $4,18(1,00-5,00)$ & & \\
\hline \multirow{2}{*}{$\begin{array}{l}\text { Unethical } \\
\text { Behavior }\end{array}$} & $2.57 \pm 0.74$ & $2.71 \pm 0.80$ & \multirow{2}{*}{-1.052} & \multirow{2}{*}{0.293} \\
\hline & $2.56(1,11-4,33)$ & $2.61(1.11-4.89)$ & & \\
\hline
\end{tabular}

There is no statistically significant difference in terms of "ethical leadership" scale score among those with the license in question and without $(\mathrm{p}=0,301)$. There is a statistically significant difference in terms of "ethical climate" scale score among those with the license in question and without $(\mathrm{p}=0,047)$. There is a statistically significant difference in terms of "unethical behaviour" scale score among those with the license in question and without $(\mathrm{p}=0,293)$

Table 11: Comparisons According to Holding Credit Rating License

\begin{tabular}{|c|c|c|c|c|}
\hline & \multicolumn{2}{|c|}{ Holding Credit Rating License } & & \\
\hline & Yes & No & \multirow{2}{*}{$\mathbf{z}$} & \multirow{2}{*}{$\mathbf{p}$} \\
\hline & $(n=134)$ & $(n=166)$ & & \\
\hline \multirow{2}{*}{ Ethical Leadership } & $3.71 \pm 0.83$ & $3.75 \pm 0.82$ & \multirow{2}{*}{-0.208} & \multirow{2}{*}{0.835} \\
\hline & $3.90(1.70-5.00)$ & $3.80(1.70-5.00)$ & & \\
\hline \multirow{2}{*}{ Ethical Climate } & $3.85 \pm 1.03$ & $4.14 \pm 0.84$ & \multirow{2}{*}{-2.133} & \multirow{2}{*}{0.033} \\
\hline & $4.23(1.00-5.00)$ & $4.36(1.09-5.00)$ & & \\
\hline \multirow{2}{*}{ Unethical Behavior } & $2.66 \pm 0.76$ & $2.62 \pm 0.78$ & \multirow{2}{*}{-0.292} & \multirow{2}{*}{0.77} \\
\hline & $2.56(1,11-4,44)$ & $2,67(1,11-4,89)$ & & \\
\hline
\end{tabular}

There is no statistically significant difference in terms of "ethical leadership" scale score among those with the license in question and without $(\mathrm{p}=0,835)$. There is a statistically significant difference in terms of "ethical climate" scale score among those with the license in question and without $(\mathrm{p}=0,033)$. There is no statistically significant difference in terms of "unethical behaviour" scale score among those with the license in question and without $(\mathrm{p}=0,770)$.

Table 12. Comparisons According To Holding Housing Valuation License

\begin{tabular}{|c|c|c|c|c|}
\hline & \multicolumn{2}{|c|}{ Holding Housing Valuation License } & \multirow{3}{*}{$\mathbf{z}$} & \multirow{3}{*}{$\mathbf{p}$} \\
\hline & Yes & No & & \\
\hline & $(n=135)$ & $(n=165)$ & & \\
\hline \multirow{2}{*}{ Ethical Leadership } & $3.60 \pm 0.85$ & $3.85 \pm 0.79$ & \multirow{2}{*}{-2.607} & \multirow{2}{*}{0.009} \\
\hline & $3,60(1,70-5,00)$ & $4,00(1,70-5,00)$ & & \\
\hline \multirow{2}{*}{ Ethical Climate } & $3.90 \pm 1.03$ & $4.10 \pm 0.84$ & \multirow{2}{*}{-1.422} & \multirow{2}{*}{0.155} \\
\hline & $4.27(1.00-5.00)$ & $4.36(1.91-5.00)$ & & \\
\hline \multirow{2}{*}{ Unethical Behavior } & $2.73 \pm 0.77$ & $2.56 \pm 0.77$ & \multirow{2}{*}{-1.677} & \multirow{2}{*}{0.094} \\
\hline & $2.56(1,11-4,44)$ & $2.56(1.22-4.89)$ & & \\
\hline
\end{tabular}

There is a statistically significant difference in terms of "ethical leadership" scale score among those with the license in question and without $(\mathrm{p}=0,009)$. There was no statistically significant difference in terms of "ethical climate" scale score between those who have the relevant license and those who do not $(\mathrm{p}=0,155)$. There was no statistically significant difference in terms of "unethical behavior" scale score between those with and without the relevant license $(\mathrm{p}=0.094)$. 
Avrupa Bilim ve Teknoloji Dergisi

Table 13: Comparisons According to Holding Risk Management Assurance Certificate

\begin{tabular}{|c|c|c|c|c|}
\hline & \multicolumn{2}{|c|}{ Holding Risk Management Assurance Certificate } & \multirow{3}{*}{$\mathbf{z}$} & \multirow{3}{*}{$\mathbf{p}$} \\
\hline & Yes & No & & \\
\hline & $(n=89)$ & $(n=211)$ & & \\
\hline \multirow{2}{*}{ Ethical Leadership } & $3.75 \pm 0.84$ & $3.73 \pm 0.82$ & \multirow{2}{*}{-0.296} & \multirow{2}{*}{0.767} \\
\hline & $3.90(1.70-5.00)$ & $3.80(1.70-5.00)$ & & \\
\hline \multirow{2}{*}{ Ethical Climate } & $3.98 \pm 0.98$ & $4.03 \pm 0.92$ & \multirow{2}{*}{-0.046} & \multirow{2}{*}{0.963} \\
\hline & $4.36(1.09-5.00)$ & $4.27(1.00-5.00)$ & & \\
\hline \multirow{2}{*}{ Unethical Behavior } & $2.61 \pm 0.75$ & $2.65 \pm 0.78$ & \multirow{2}{*}{-0.223} & \multirow{2}{*}{0.823} \\
\hline & $2.56(1.11-4.4)$ & $2.56(1,11-4,89)$ & & \\
\hline
\end{tabular}

There is a statistically significant difference in terms of "ethical leadership" scale score between position in the institution ( $p<0,001)$. There is a statistically significant difference in terms of "ethical climate" scale score between position in the institution ( $<<0,001)$. There is no statistically significant difference in terms of "unethical behaviour" scale score between position in the institution $(\mathrm{p}=0,580)$.

\section{Conclusion and Suggestions}

There were no statistically significant differences in terms of "ethical leadership" scale scores between males and females in this study and there was a significant difference in terms of "ethical leadership" and "ethical climate" between married and single individuals observed. The desire of married individuals to work in a more stable environment and tend to be less risky also lead to the valuing of ethical leadership and ethical climate. Single individuals can be interpreted as being more prone to take risks and change jobs. Since married people will act with the instinct to protect their family environment, there is a desire to work in a more ethical environment.

When we look at educational status and education areas, there was a statistically significant difference between "ethical leadership" and "ethical climate" scale scores. When it is examined which group or groups the difference is between; There was a statistically significant difference between "associate degree" and "graduate / doctorate" groups and between "degree" and "graduate / doctorate" groups but no significant difference between "degree" and "associate degree" groups. While there is a statistically significant difference between the education groups in terms of "ethical climate" scale point, when the group or group in which the difference is found is examined; There was a statistically significant difference between "associate degree" and "graduate / doctorate" groups and between "degree" and "graduate / doctorate" groups but no significant difference between "degree" and "associate degree" groups. There was no statistically significant difference between the education groups in terms of "unethical behavior" scale score. In this respect, it is revealed that the education variable does not have any influence on ethical behavior change but it is an important variable having an influence in terms of ethical leadership and ethical climate. As the level of education increases, the tendency towards a specific field also increases, which leads to a tendency to show more ethical behavior.

When we look at age by comparison, there is a significant difference between " ethical leadership " and " ethical climate " and the interval with the most difference is 51-60 years. According to the studies carried out, cognitive development will increase as the age increases and the ethical behavior can be interpreted as increasing with it. The ethical perception in Corporate Governance is also changing in this way and it can be interpreted as the necessity of departing from the environment in which people work by perceiving institutional loyalty and protecting ethical standards and ethical climate and ethical leadership.

In our study, there was a significant and positive relationship between the ethical leadership and the ethical climate for the 30-factor 3 -scale structure in the analysis by applying the Confirmatory Factor Analysis (Structural Equation Model). There was a negative relationship between ethical leadership-unethical behavior and ethical climate-unethical behavior. This shows the direction of the relationship between them.

Morality includes the conduct and rules in society that individuals are obliged to obey. In this respect, the development of morality involves a kinetic development as a result of the experiences of individuals and not a lack of progression. While laws appear as compelling, written provisions, ethical values make the individual responsible for decisions taken. Morality can be concluded to be the result of evaluating the justifications of ethical behavior while creating patterns of behavior and rules that individuals must obey.

It is not possible to find activities that are against human rights often in a tolerant society that is as pleasant as possible with a sense of love and understanding. Ethical culture must be adopted in order to construct the mentioned social structure.

Moving towards business ethics is an opportunity for both business people and organizations. Businesses and organizations need to be able to apply the values recognized as human values to their working lives.

It is also seen from our study that if a staff member of the organization thinks that he or she has not been treated fairly and certain members of staff are treated with privilege, it can be said that the ethical behavior in the institution is not internalized even if the organization has set ethical codes. Therefore, it can be said that the institutional injustice perceived by the staff will negatively affect the perception of ethics regarding the institution. In organizations where the codes of ethics are important and communication is strong, the staff are more likely to behave in conformity with the behaviors to be avoided or complied with in the framework of corporate governance. 
As seen in our study, it is observed that the ethical perception in Corporate Governance changes according to marital status, age, education status, position in the institution, duration at the institution and total duration of work. It has been seen that these changes have an effect on the ethical perception of the institution. It is envisaged that the ethical perception in Corporate Governance will be created by internalization of the ethical perception in addition to the written rules of ethics with the training given to propogate it among the staff at every level of the bank.

\section{References}

Acar, A. (2013). Z. Farklı Örgüt Kültürü Tipleri Ve Liderlik Tarzları Ile Örgütsel Bağlılık Arasındaki İlişki: Lojistik İşletmelerinde Bir Araştırma. Farklı Örgüt Kültürü Tipleri Ve Liderlik Tarzları Ile Örgütsel Bağlılık Arasındaki İlişki: Lojistik İşletmelerinde Bir Araştırma, V. 5, N. 2, 5-31.

Akdoğan, A. VE Demirtaş. (2014.) Ö. Etik Liderlik Davranışlarının Etik İklim Üzerindeki Etkisi: Örgütsel Politik Algılamaların Arac1 Rolü. Journal Of Economics And Administrative Sciences, V. 16, N. 1, 107-123.

Ateş, H.; ORAL. (2003). B. Kamu Yönetiminde Etik: Kültürel Temeller Ve "Örgütsel Ruhçuluk” Kuramı Ekseninde Bir Analiz. Kocaeli Üniversitesi Sosyal Bilimler Enstitüsü Dergisi, V. 5, N. 1, 55-71.

Aydın, İ. (2016). Yönetsel, Mesleki Ve Örgütsel Etik, Pegem Akademi Yayınları,7.Baskı,Ankara.

Aykanat, Z. (2010). Karizmatik Liderlik Ve Örgüt Kültürü İlişkisi Üzerine Bir Uygulama. Karamanmehmetbey Üniversitesi Sosyal Bilimler Enstitüsü, Yüksek Lisans Tezi.

Barnett, T. Ve Schubert E. (2002). Perceptions Of The Ethical Work Climate And Covenantal Relationships. Journal Of Business Ethics, V. 36, N. 1, 279-290..

Brown, M. E., Trevino, L. K. And Harrison, D. A. (2005). Ethical Leadership: A Social Learning Perspective For Construct Development And Testing. Organizational Behavior And Human Decision Processes , V. 97, N. 1, 117-134.

Byrne, B. M. .(1989). A Primer Of Lisrel: Basic Applications And Programming For Confirmatory Factor Analytic Models. New York: Springer-Verlag.

Demirdağ, G. E. VE Ekmekçioğlu, E. B. (2015) Etik İklim Ve Etik Liderliğin Örgütsel Bağl1lık Üzerine Etkisi: Görgül Bir Araştırma. Gazi Üniversitesi İktisadi Ve İdari Bilimler Fakültesi Dergisi, V. 17, N. 1, 197-216.

Doğan, S. VE Kılıç, S. (2014), Üretkenlik Karşıtı İş Davranışlarının Türleri, Boyutları Ve Benzer Kavramlarla İlişkilerine Yönelik Bir Yazın İncelemesi. H.Ü. İktisadi Ve İdari Bilimler Fakültesi Dergisi, V. 32, N. 2, 103-132.

Eren, E. (2012). Örgütsel Davranış Ve Yönetim Psikolojisi, Beta Yayınları,13.bask1,İstanbul.

Kline, R. B. (2011). Principles And Practice Of Structural Equation Modeling. London: The Guilford Press

Murphy, P. E. And Enderle, G. (1995). Managerial Ethical Leadership: Examples Do Matter. Business Ethics Quarterly., V. 5, N. 1, P. 117-128.

Özgener, Ş. (2002). İmalat Sanayii İşletmelerindeki Kamu Ve Özel Sektör Yöneticilerinin İş Ahlakına İlişkin Tutumları. Amme İdaresi Dergisi, V. 35, N. 1, 175-199.

Pettijohn, C., Pettijohn. (2008). L. And Taylor, A.J. Salesperson Perceptions Of Ethical Behaviors: Their Influence On Job Satisfaction And Turnover Intentions. Journal Of Business Ethics, V. 78, $547-557$.

Sayğan, S.; BEDÜK. (2013). A. Ahlaki Olmayan Davranışların Duyurulması (Whistleblowing) Ve Etik İklimi İlişkisi Üzerine Bir Uygulama. Dokuz Eylül Üniversitesi İktisadi Ve İdari Bilimler Fakültesi Dergisi, V. 28, N. 1, 1-23.

Schwepker, C. H. (1997) Ferrel, O. C. And Ingram, T. N.. The Influence Of Ethical Climate And Ethical Conflict On Role Stress In The Sales Force. Journal Of The Academy Of Marketing Science, V. 25, N. 2, 99-108.

Şimşek, Ö. F. (2007). Yapısal Eşitlik Modellemesine Giriş - Temel İlkeler Ve LISREL Uygulamaları. İstanbul: Ekinoks Yayınları.

Tuna, M. Ve Yeşiltaş. (2013). M. Liderliğin Etik Boyutu: Etik Liderliğin Otel İşletmelerindeki İşgörenler Tarafından Algılanması. İşletme Araştırmaları Dergisi, V. 5, N. 3, 184-209 